\title{
Potensi Zeolit Alam Ende-NTT sebagai Katalis Transformasi Senyawa Gula Menjadi 5-Hidroksimetilfurfural (HMF)
}

\section{The potency of Ende-NTT Natural Zeolite as a Catalyst for Transforming Sugar Compounds into 5-Hydroxymethylfurfural (HMF)}

\author{
Mela Faradika, Sri Sugiarti", Purwantiningsih Sugita \\ Departemen Kimia, Fakultas Matematika dan Ilmu Pengetahuan Alam, Institut Pertanian Bogor Kampus IPB \\ Dramaga Jl.Agatis Wing 2 Level 4, Bogor 16144, Indonesia \\ *Corresponding author: srisugiarti@apps.ipb.ac.id
}

Received: June 2018; Revised: August 2018; Accepted: February 2019; Available Online: May 2019

\begin{abstract}
Abstrak
Sintesis 5-hidroksimetilfurfural (HMF) dari senyawa gula (glukosa dan fruktosa) dengan katalis zeolit alam Ende-Nusa Tenggara Timur (NTT) menggunakan pelarut dimetil-sulfoksida (DMSO) dan metode refluks telah dilakukan. Penelitian ini bertujuan untuk melihat efektivitas zeolit alam Ende sebagai katalis transformasi senyawa gula menjadi 5-hidroksimetilfurfural (HMF). Hasil penelitian menunjukkan bahwa zeolit alam Ende tanpa aktivasi dan modifikasi (ZA), zeolit teraktivasi asam (ZAA), zeolit teraktivasi basa (ZAB), Na-zeolit teraktivasi asam (Na-ZAA), Na-zeolit teraktivasi basa (Na-ZAB), H-zeolit teraktivasi asam (H-ZAA), dan H-zeolit teraktivasi basa (H-ZAB) memiliki potensi sebagai katalis untuk transformasi senyawa gula menjadi HMF. Rendemen yang dihasilkan untuk substrat fruktosa berkisar 43-74\%, sedangkan untuk substrat glukosa berkisar 2-12\%. ZAA memiliki aktivitas katalitik terbaik sebagai katalis dalam mengkonversi fruktosa menjadi HMF dengan rendemen $74.84 \%$, sedangkan untuk substrat glukosa adalah katalis H-ZAA dengan rendemen sebesar $12.77 \%$.
\end{abstract}

Kata kunci: 5-Hidroksimetilfurfural (HMF), fruktosa, glukosa, katalis, zeolit.

\begin{abstract}
The synthesis of 5-hydroxymethylfurfural (HMF) from sugars (glucose and fructose) with natural zeolite catalyst of Ende-Nusa Tenggara Timur (NTT) in dimethyl-sulfoxide (DMSO) using reflux method has been done. This study aims to observe the ability of natural zeolite Ende as a catalyst for the transformation of sugar compounds into HMF. According to the research, Ende natural zeolite without activation and modification (ZA), acid activation zeolite (ZAA), alkaline activation zeolite (ZAB), acid activation Na-zeolite (Na-ZAA), alkaline activation Na-zeolite (Na-ZAB), acid activation H-zeolite (H-ZAA) and alkaline activation H-zeolite (H-ZAB) have the ability to transform sugar compounds into HMF. HMF yield for fructose as a substrate was $43-74 \%$, while those for glucose as a substrate was $2-12 \%$. ZAA catalyst had the best catalytic activity as a catalyst in converted fructose to HMF with yield was $74.84 \%$, while for glucose substrate was H-ZAA catalyst with yield was $12.77 \%$.
\end{abstract}

Keywords: 5-Hydroxymethylfurfural (HMF), catalyst, fructose, glucose, zeolite.

DOI: $10.15408 / j k v . v 1 i 1.8174$

\section{PENDAHULUAN}

Senyawa gula sederhana seperti glukosa dan fruktosa dapat digunakan sebagai bahan baku untuk menghasilkan senyawa 5-Hidroksimetilfurfural (HMF). HMF adalah senyawa intermediet yang disebut sebagai "sleeping giants" karena kemampuannya sebagai molekul prekursor untuk produksi dimetilfuran (DMF), asam levulinat, asam 2,5furandikarboksilat (FDA), 2,5-diformilfuran (DFF), 3,5-dihidroksimetilfuran, dan molekul penting lainnya (Yongdan et al., 2010). 
Senyawa-senyawa turunan dari HMF tersebut dapat dimanfaatkan sebagai bahan baku pembuatan bahan-bahan kimia seperti furfural alkohol, plastik, obat-obatan (seperti prekursor antiviral hepatitis), dan bahan bakar hidrokarbon cair (Hu et al., 2013; Liu et al., 2013; Resasco et al., 2011).

HMF disintesis dari reaksi dehidrasi fruktosa melalui hilangnya 3 molekul air (Qiao et al., 2015). Produksi HMF dari glukosa dilakukan melalui proses isomerisasi terlebih dahulu menjadi fruktosa, kemudian dehidrasi fruktosa akan menghasilkan HMF. Proses isomerisasi dan dehidrasi dapat berjalan dengan adanya katalis asam homogen maupun heterogen. Penelitian yang dilakukan Zhou et al., (2016), menunjukkan bahwa katalis yang efektif untuk reaksi konversi glukosa menjadi HMF adalah $\mathrm{CrCl}_{3}$ dan $\mathrm{AlCl}_{3}$ menggunakan pelarut DMSO dengan rendemen sebesar $54.43 \%$ dan $52.86 \%$. Logam-logam klorida tersebut memang sangat berpotensi sebagai katalis untuk menghasilkan HMF. Akan tetapi, penggunaan katalis logam yang merupakan katalis homogen memiliki kekurangan, diantaranya sulit untuk diregenerasi dan dipisahkan jika dibandingkan dengan katalis heterogen.

Salah satu katalis heterogen yang berpotensi untuk produksi HMF adalah zeolit. Shimizu et al., (2009), telah menggunakan katalis H-BEA zeolit dan H-Y zeolit untuk konversi fruktosa menjadi HMF dengan rendemen sebesar $97 \%$ dan $76 \%$. Jae et al., (2011), juga telah menguji berbagai zeolit untuk konversi biomassa menjadi senyawa aromatik. Berbagai macam zeolit sintesis berdasarkan ukuran pori telah diuji untuk konversi tersebut. Terdapat 3 jenis zeolit berdasarkan ukuran porinya, yaitu zeolit berpori kecil (ZK-5 dan SAPO-34), zeolit berpori sedang (ZSM-23, MCM-22, SSZ-20, ZSM-11, ZSM-5, IM-5, dan TNU-9), dan zeolit berpori besar (SSZ-55, zeolit Beta, zeolit Y). Zeolit berpori kecil tidak menghasilkan aromatik dengan produk beroksigen (dari pirolisis glukosa), $\mathrm{CO}, \mathrm{CO}_{2}$, dan karbon padat sebagai produk utama. Zeolit berpori sedang (ZSM-5 dan ZSM-11) memiliki hasil aromatik tertinggi dan jumlah karbon padat paling sedikit (Jae et al., 2011).

Katalis zeolit yang digunakan dari penelitian sebelumnya merupakan katalis zeolit sintetis. Zeolit sintetis memiliki kristalinitas tinggi, oksida logam dalam jumlah yang minimum serta aktivitas katalitiknya tinggi (Wustoni et al., 2011). Akan tetapi, kelemahan dari zeolit sintetis tidak tahan pada suhu yang tinggi dan untuk membuat zeolit sintetis membutuhkan biaya tinggi (Syafii et al., 2010). Oleh karena itu, dalam penelitian ini memanfaatkan zeolit alam sebagai sumber katalis. Selain keberadaannya melimpah di alam, zeolit alam juga memiliki kestabilan termal yang baik (Wang et al., 2009). Salah satu zeolit alam di Indonesia yang kelimpahannya tinggi, tetapi pemanfaatannya belum maksimal adalah zeolit alam Ende dari Nusa Tenggara Timur (NTT). Namun, zeolit alam memiliki aktivitas katalitik yang rendah, mengandung oksida logam dalam jumlah yang banyak, dan ukuran porinya sangat tidak seragam (Syafii et al., 2010). Oleh sebab itu, untuk meningkatkan aktivitas katalitiknya perlu dilakukan proses akivasi dan modifikasi pada katalis zeolit Ende.

\section{METODE PENELITIAN Ruang Lingkup Penelitian}

Penelitian ini dibagi atas beberapa tahapan, yaitu pengambilan sampel zeolit alam yang berasal Ende-NTT. Preparasi dan aktivasi zeolit alam, sintesis katalis $\mathrm{H}-Z$ Zeolit dari $\mathrm{Na}-$ zeolit, karakterisasi zeolit menggunakan XRD (untuk mengetahui jenis zeolit alam dan mengamati perubahan struktur yang terjadi). Tahapan selanjutnya adalah konversi HMF dari fruktosa dan glukosa menggunakan metode refluks, kemudian HMF dikarakterisasi menggunakan HPLC.

\section{Alat dan Bahan}

Bahan-bahan yang digunakan adalah fruktosa (Merck), glukosa (Merck), $\mathrm{HCl}$ (Merck), akuades, $\mathrm{NaOH}$ (Merck), $\mathrm{NH}_{4} \mathrm{Cl}$ (Merck), DMSO (Merck), standar HMF (Sigma Aldrich) dan zeolit alam yang berasal dari kabupaten Ende-NTT. Zeolit dikarakterisasi menggunakan spektroskopi difraksi sinar-X (XRD) PAN-Analytical. Senyawa HMF dikarakterisasi menggunakan kromatografi cair tingkat tinggi (HPLC) Shimadzu LC-20AD.

\section{Preparasi dan Aktivasi Zeolit Alam}

Zeolit Alam Ende (ZA) digerus dengan mortar dan disaring dengan ayakan 100 mesh. Kemudian zeolit direndam dengan akuades pada suhu kamar selama 24 jam. Setelah itu disaring dan dikeringkan pada suhu 
$100{ }^{\circ} \mathrm{C}$ selama 3 jam. Selanjutnya zeolit diaktivasi secara kimia menggunakan larutan $\mathrm{HCl} 1 \mathrm{M}$ untuk aktivasi asam dan $\mathrm{NaOH} 1 \mathrm{M}$ untuk aktivasi basa. Kemudian zeolit dikeringkan pada suhu $130{ }^{\circ} \mathrm{C}$ selama 3 jam sehingga diperoleh zeolit aktivasi asam (ZAA) dan zeolit aktivasi basa (ZAB).

\section{Sintesis Katalis H-Zeolit dari Na-Zeolit}

Zeolit alam yang telah diaktivasi direndam dalam larutan $\mathrm{NaOH} 2 \mathrm{M}$ selama 24 jam. Kemudian sampel disaring dan dicuci dengan akuades hingga $\mathrm{pH}$ filtratnya netral. Setelah itu dikeringkan di dalam oven dengan suhu $130{ }^{\circ} \mathrm{C}$ selama 3 jam sehingga diperoleh Na-Zeolit aktivasi asam (Na-ZAA) dan Na-Zeolit aktivasi basa (Na-ZAB). Na-ZAA dan Na-ZAB dikonversi menjadi H-Zeolit aktivasi asam (H-ZAA) dan H-Zeolit aktivasi basa $(\mathrm{H}-\mathrm{ZAB})$ untuk meningkatkan keasaman dengan cara pengubahan ion dengan ditambahkan $\mathrm{NH}_{4} \mathrm{Cl} 1 \mathrm{M}$ selama 24 jam. H-ZAA dan H-ZAB yang terbentuk disaring, dicuci sampai $\mathrm{pH}$ netral, dan dikeringkan pada suhu $130{ }^{\circ} \mathrm{C}$ selama 3 jam. Padatan yang terbentuk dikalsinasi pada suhu $550{ }^{\circ} \mathrm{C}$ selama 5 jam. Selanjutnya, katalis zeolit hasil sintesis yang diperoleh dicirikan menggunakan XRD.

\section{Analisis Keasaman Katalis Zeolit dengan Adsorpsi Piridin Menggunakan Metode Gravimetri}

Analisis keasaman katalis dilakukan dengan menggunakan adsorpsi piridin. Krus porselen dipanaskan dalam oven pada temperatur $120{ }^{\circ} \mathrm{C}$, setelah itu didinginkan dan ditimbang bobotnya. Sebanyak $0.5 \mathrm{~g}$ masingmasing katalis zeolit (ZA, ZAA, Na-ZAA, HZAA, ZAB, Na-ZAB, H-ZAB) dimasukkan ke dalam krus porselen. Krus dan zeolit serta sebanyak $15 \mathrm{~mL}$ piridin dimasukkan ke dalam desikator selama 24 jam. Setelah 24 jam, katalis yang telah mengadsorpsi piridin ditimbang bobotnya.

Keasaman katalis $=\frac{\mathrm{W} \text { piridin }(\mathrm{g})}{\mathrm{BM} \text { piridin }\left(\frac{\mathrm{g}}{\mathrm{mol}}\right) \times \mathrm{W} \text { katalis }(\mathrm{g})} \times 1000$

\section{Sintesis HMF dari Fruktosa dan Glukosa}

Proses konversi HMF dari fruktosa dan glukosa dilakukan menggunakan metode refluks di dalam oil bath yang dialiri gas $\mathrm{N}_{2}$. Sebanyak $0.01 \mathrm{~g}$ katalis $\left(\mathrm{CrCl}_{3} /\right.$ zeolit aktivasi/Na-zeolit /H-zeolit) ditambahkan ke dalam $15 \mathrm{~mL}$ DMSO. Kemudian ke dalam campuran ditambahkan $0.15 \mathrm{~g}$ substrat (fruktosa/glukosa), lalu diaduk menggunakan pengaduk magnetik dengan kecepatan $600 \mathrm{rpm}$ pada suhu $120^{\circ} \mathrm{C}$ selama 2 jam untuk fruktosa dan 6 jam untuk glukosa. Hasil reaksi konversi fruktosa dan glukosa dicirikan menggunakan HPLC (kolom C18 dan detektor UV dengan panjang gelombang $284 \mathrm{~nm}$ ) untuk mendeteksi keberadaan HMF dengan fase gerak berupa air:metanol dengan rasio 95:5.

\section{HASIL DAN PEMBAHASAN}

Zeolit Teraktivasi dan Termodifikasi

Preparasi awal dilakukan dengan menghaluskan zeolit alam yang berasal dari Ende-NTT hingga dihasilkan serbuk zeolit yang lolos ayakan 100 mesh. Pengubahan ukuran zeolit bertujuan untuk menghomogenkan ukuran dan memperluas permukaan kontak sehingga jumlah sisi katalitiknya lebih meningkat. Proses pencucian dan pemanasan pada tahap preparasi bertujuan untuk menghilangkan pengotor dan menguapkan air yang terjerap pada pori zeolit. Hasil analisis XRD yang dilakukan tehadap zeolit dapat dilihat pada gambar 1 .

Gambar 1 menunjukkan bahwa jenis zeolit alam ini adalah campuran mordenit dan klinoptilolit. Hal ini didasarkan pada munculnya puncak-puncak sudut $2 \theta$ yang sesuai dengan karakter puncak pada data Joint Committee on Powder Diffraction Standard (JCPDS) No. 06-0239 untuk mordenit dan No. 47-1870 untuk klinoptilolit. Zeolit jenis mordenit pada penelitian ini ditunjukkan oleh puncak dengan intensitas tertinggi pada sudut $2 \theta 25.60^{\circ}, 26.62^{\circ}$, dan $27.49^{\circ}$, sedangkan untuk jenis klinoptilolit pada sudut $2 \theta 9.74^{\circ}$, $13.41^{\circ}$ dan $20.84^{\circ}$. Nilai ini sesuai dengan yang pernah dilaporkan oleh Ngapa et al., (2016). Hasil penelitian Ngapa et al., (2016) melaporkan bahwa zeolit Ende merupakan jenis campuran mordenit dan klinoptilolit dengan data intensitas puncak tertinggi yang muncul untuk zeolit Ende jenis mordenit terdapat pada sudut $2 \theta 25.63^{\circ}, 26.25^{\circ}$ dan $27.67^{\circ}$, sedangkan untuk jenis klinoptilolit muncul pada sudut $2 \theta 13.38^{\circ} 22.36^{\circ}$, dan $29.07^{\circ}$.

Zeolit mordenit merupakan salah satu material yang potensial untuk digunakan menjadi katalis karena keasamannya dapat ditingkatkan melalui proses aktivasi dan kalsinasi pada suhu tinggi (Gultom et al., 2015). Aktivasi zeolit dilakukan secara kimia 
dengan penambahan $\mathrm{HCl} 1 \mathrm{M}$ dan $\mathrm{NaOH} 1 \mathrm{M}$. Proses aktivasi menggunakan asam bertujuan untuk melarutkan oksida-oksida logam yang menutupi permukaan zeolit sehingga permukaan bidang kontak menjadi lebih besar, sedangkan proses aktivasi menggunakan basa bertujuan agar permukaan zeolit menjadi lebih negatif (Kim dan Ahn, 2011). Hasil analisis XRD yang dilakukan terhadap zeolit alam Ende-NTT setelah proses aktivasi ditunjukkan pada Gambar 1. Gambar 1 menunjukkan bahwa perlakuan aktivasi dengan $\mathrm{HCl}$ dan $\mathrm{NaOH} 1 \mathrm{M}$ tidak mengubah puncak-puncak difraktogram secara signifikan. Hal ini disebabkan karena struktur zeolit alam yang relatif stabil (Ngapa et al., 2016).

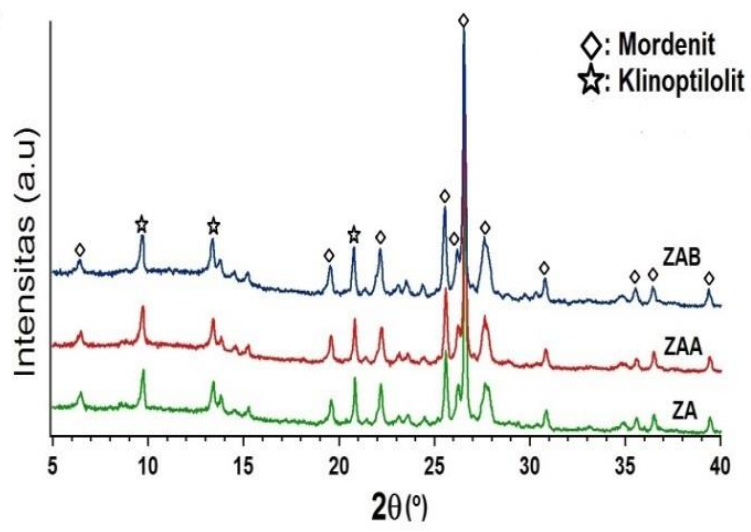

Gambar 1. Difraktogram ZA, ZAA, dan ZAB

Katalis H-ZAA dan H-ZAB yang digunakan untuk konversi fruktosa dan glukosa menjadi HMF disintesis melalui Na-ZAA dan $\mathrm{Na}-\mathrm{ZAB}$. Pembentukan Na-ZAA dan Na-ZAB dilakukan melalui distribuasi ion $\mathrm{Na}^{+}$dari larutan $\mathrm{NaOH} 2 \mathrm{M}$ pada zeolit alam yang telah teraktivasi. Selanjutnya Na-ZAA dan Na-ZAB yang diperoleh ditambahkan larutan garam asam $\left(\mathrm{NH}_{4} \mathrm{Cl}\right)$ untuk membentuk H-ZAA dan $\mathrm{H}-\mathrm{ZAB}$ melalui pertukaran ion (Adeoye et al., 2017). Proses pemanasan atau kalsinasi saat pembentukan H-ZAA dan H-ZAB bertujuan untuk menguapkan $\mathrm{NH}_{3}$ dengan meninggalkan proton dan menguapkan molekul air yang terjerap pada zeolit (Warner et al., 2017). Ion $\mathrm{H}^{+}$dapat mengkatalisis dehidrasi fruktosa menjadi HMF (Lei et al., 2013). Hasil analisis XRD Na-ZAA, Na-ZAB, H-ZAA, dan H-ZAB dapat dilihat pada Gambar 2. Gambar 2 menunjukkan bahwa tidak terjadi perubahan puncak difraktogram, hanya saja terjadi sedikit perubahan intensitas. Jadi, selain memiliki struktur yang stabil, zeolit alam Ende-NTT juga memiliki ketahanan yang baik terhadap panas.
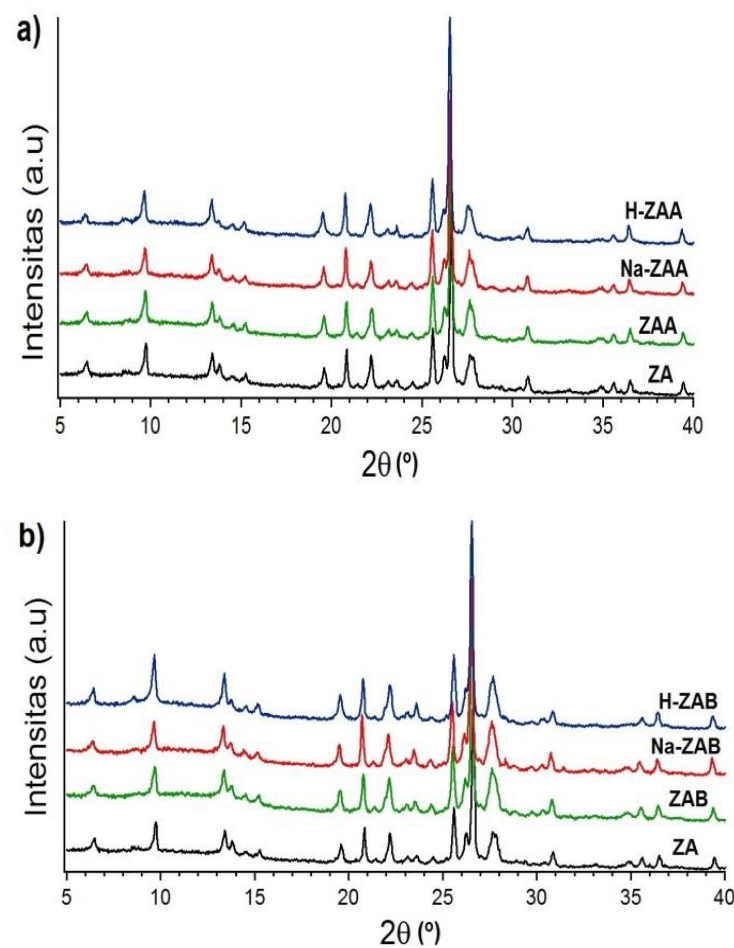

Gambar 2. a) Difraktogram ZA, ZAA, Na-ZAA, dan H-ZAA b) Difraktogram ZA, ZAB, Na-ZAB, dan $\mathrm{H}-\mathrm{ZAB}$

Tabel 1. Data kristalinitas zeolit Ende-NTT

\begin{tabular}{lc}
\hline Sampel & $\begin{array}{c}\text { Derajat Kristalinitas } \\
(\boldsymbol{\%})\end{array}$ \\
\hline ZA & 59.73 \\
ZAA & 54.40 \\
Na-ZAA & 62.91 \\
H-ZAA & 61.46 \\
ZAB & 61.29 \\
Na-ZAB & 61.52 \\
H-ZAB & 60.05 \\
\hline
\end{tabular}

Kristalinitas masing-masing zeolit dapat dilihat pada Tabel 1. Tabel 1 menunjukkan bahwa Na-ZAA memiliki derajat kristalinitas yang paling tinggi sebesar $62.91 \%$. Semakin tinggi derajat kristalinitas maka sampel zeolit semakin bersifat kristal. Sifat kristal inilah yang diharapkan pada suatu katalis. Jika dilihat pada Tabel 1, ketika dilakukan aktivasi asam (ZAA) terjadi penurunan derajat kristalinitas, yaitu $54.40 \%$. Turunnya derajat kristalinitas ini, disebabkan 
karena terjadinya dealuminasi pada sampel zeolit yang mengakibatkan runtuhnya sebagian ikatan Al-O pada zeolit (Silaghi et al., 2016). Ketika dilakukan penambahan ion $\mathrm{Na}^{+}$dari larutan $\mathrm{NaOH}$ diduga terjadi penataan ulang struktur zeolit sehingga derajat kristalinitasnya meningkat menjadi $62.91 \%$. Sedangkan untuk aktivasi basa (ZAB dan Na-ZAB), derajat kristalinitas cenderung meningkat, yaitu $61.29 \%$ dan $61.52 \%$. Hal ini disebabkan karena penambahan larutan basa dapat melarutkan pengotor pada zeolit, sehingga zeolit lebih bersifat kristal.

\section{Keasaman Katalis Zeolit Ende}

Keasaman (acidity) suatu katalis didefinisikan sebagai kemampuan katalis dalam mengadsorpsi uap basa, seperti amonia, piridin atau $n$-butilamina karena adanya situs asam Brønsted maupun situs asam Lewis pada permukaan katalis sebagai jumlah mmol basa yang teradsorpsi per gram sampel padatan (Trisunaryanti, 2016). Hasil penentuan keasaman masing-masing katalis zeolit Ende yang dilakukan dengan adsorpsi piridin menggunakan metode gravimetri ditampilkan pada Tabel 2.

Tabel 2. Keasaman katalis zeolit Ende-NTT

\begin{tabular}{ll}
\hline Sampel & $\begin{array}{l}\text { Keasaman Katalis } \\
(\mathbf{m m o l} / \mathbf{g})\end{array}$ \\
\hline ZA & 0.369 \\
ZAA & 0.624 \\
Na-ZAA & 0.667 \\
H-ZAA & 0.699 \\
ZAB & 0.623 \\
Na-ZAB & 0.633 \\
H-ZAB & 0.641 \\
\hline
\end{tabular}

Berdasarkan Tabel 2, keasaman katalis zeolit Ende meningkat dengan adanya perlakuan aktivasi asam maupun basa dan modifikasi menjadi Na-zeolit dan H-zeolit. Katalis H-ZAA memiliki keasaman yang paling tinggi, yaitu $0.699 \mathrm{~g} / \mathrm{mmol}$. Adanya peningkatan keasaman pada katalis dapat meningkatkan aktivitas katalitiknya (Gultom et al., 2015). Akan tetapi, perbedaan perlakuan aktivasi menggunakan asam dan basa tidak menunjukkan perbedaan keasaman yang signifikan.

\section{Performa Zeolit Alam pada Transformasi Fruktosa dan Glukosa menjadi HMF}

Proses konversi HMF dari senyawa gula, yaitu fruktosa dan glukosa dilakukan dengan metode refluks. Konversi diawali dengan menambahkan senyawa gula dengan katalis dan pelarut DMSO, selama proses sintesis berlangsung dialiri dengan gas $\mathrm{N}_{2}$ sehingga kondisi reaksi jenuh dengan gas $\mathrm{N}_{2}$. Jalur transformasi glukosa dan fruktosa menjadi senyawa HMF dapat dilihat pada Gambar 3.

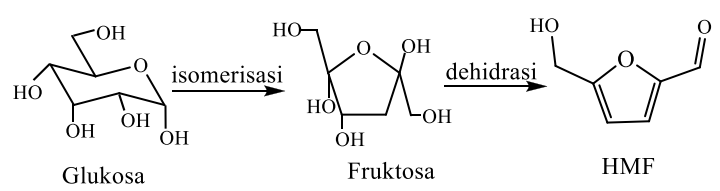

Gambar 3. Transformasi glukosa dan fruktosa menjadi senyawa HMF
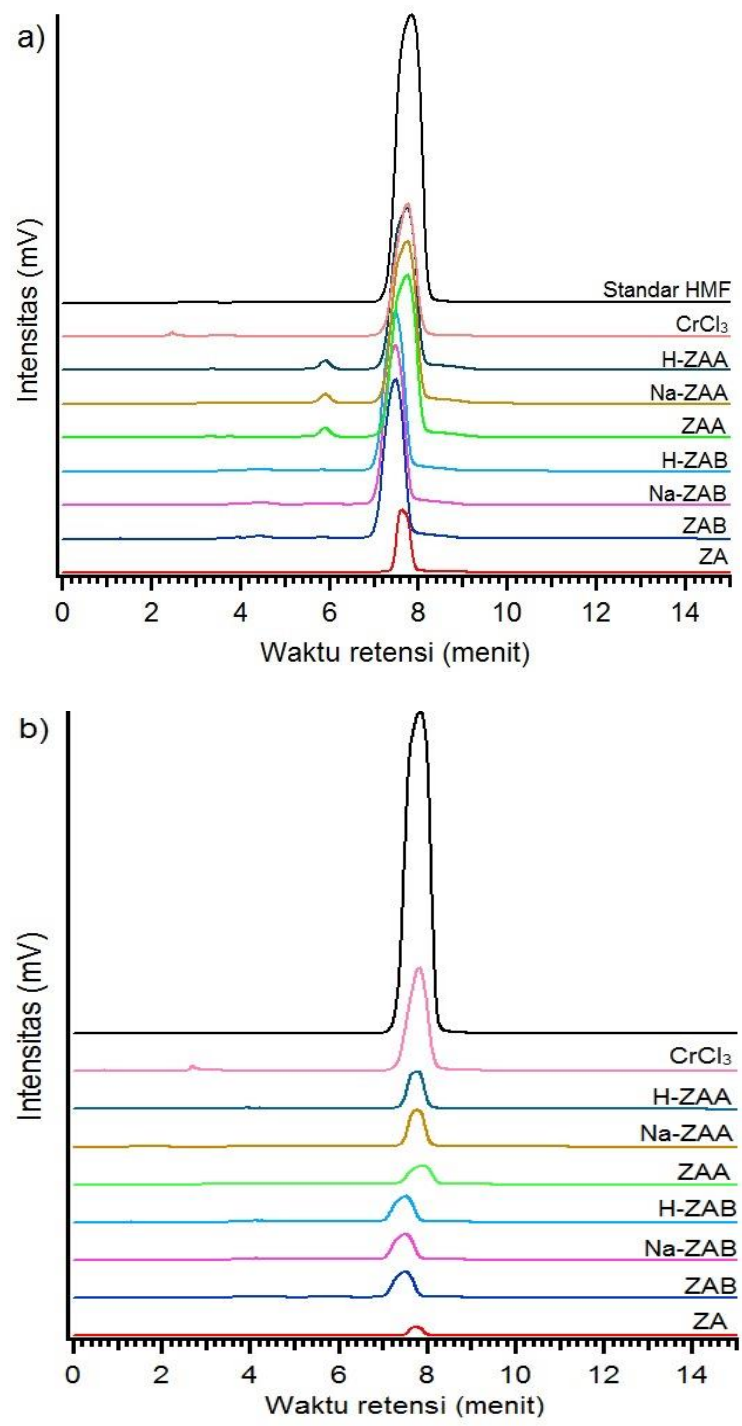

Gambar 4. Kromatogram HMF a) substrat fruktosa b) substrat glukosa 
HMF hasil konversi dari fruktosa dan glukosa dengan katalis $\mathrm{CrCl}_{3}$, ZAA, Na-ZAA, H-ZAA, ZAB, Na-ZAB, dan H-ZAB dikarakterisasi menggunkan HPLC. Katalis $\mathrm{CrCl}_{3}$ digunakan sebagai pembanding. Analisis kualitatif dan kuantitatif HMF dapat ditentukan dari perbandingan puncak kromatogram standar HMF dengan puncak kromatogram sampel hasil sintesis berdasarkan waktu retensinya (Gambar 4). Standar HMF muncul pada 7.8 menit, sedangkan HMF sintesis dengan substrat fruktosa maupun glukosa muncul pada kisaran 7.6-7.8 menit. Waktu retensi HMF sintesis mempunyai kemiripan dengan standar HMF. Hal ini mengindikasikan bahwa puncak kromatogram pada sampel hasil sintesis merupakan senyawa HMF.

Rendemen HMF hasil sintesis dari berbagai katalis yang digunakan dapat dilihat pada Tabel 2. Katalis $\mathrm{CrCl}_{3}$ memiliki kemampuan yang paling baik untuk konversi fruktosa dan glukosa dengan rendemen sebesar $94.11 \%$ dan $70.21 \%$. Hal ini disebabkan karena terbentuk kompleks logam klorida dengan glukosa yang lebih stabil. Pembentukan kompleks yang stabil tersebut dapat dihubungkan dengan keasaman lewis yang tinggi yang disebabkan oleh koordinasi yang kuat antara $\mathrm{Cl}^{-}$dengan logam pusat kromium. Koordinasi ini memiliki kemampuan untuk memudahkan proses isomerisasi dari glukosa dan fruktosa (Lewkowski, 2001).

Tabel 3. Konversi fruktosa dan glukosa menggunakan katalis $\mathrm{CrCl}_{3}$ dan zeolit alam ende

\begin{tabular}{llc}
\hline \multicolumn{1}{c}{ Katalis } & Substrat & $\begin{array}{c}\text { Rendemen } \\
\mathbf{( \% )}\end{array}$ \\
\hline $\mathrm{CrCl}_{3}$ & Fruktosa & 94.11 \\
$\mathrm{ZA}$ & Glukosa & 70.21 \\
& Fruktosa & 43.30 \\
$\mathrm{ZAA}$ & Glukosa & 2.86 \\
& Fruktosa & 74.84 \\
$\mathrm{Na}-\mathrm{ZAA}$ & Glukosa & 7.87 \\
& Fruktosa & 70.22 \\
$\mathrm{H}-\mathrm{ZAA}$ & Glukosa & 11.91 \\
& Fruktosa & 71.73 \\
$\mathrm{ZAB}$ & Glukosa & 12.77 \\
& Fruktosa & 65.33 \\
$\mathrm{Na}-\mathrm{ZAB}$ & Glukosa & 10.38 \\
& Fruktosa & 66.08 \\
$\mathrm{H}-\mathrm{ZAB}$ & Glukosa & 10.51 \\
& Fruktosa & 66.30 \\
& Glukosa & 10.05 \\
\hline
\end{tabular}

Berdasarkan Tabel 3, katalis zeolit Ende, yaitu ZA, ZAA, Na-ZAA, H-ZAA, $\mathrm{ZAB}, \mathrm{Na}-\mathrm{ZAB}, \mathrm{H}-\mathrm{ZAB}$ memiliki potensi untuk konversi fruktosa dan glukosa menjadi HMF. Adanya perlakuan aktivasi asam maupun basa dan modifikasi dalam bentuk Nazeolit dan $\mathrm{H}$-zeolit dapat meningkatkan rendemen HMF baik untuk substrat fruktosa maupun glukosa (Tabel 3). Perbedaan cara aktivasi (asam/basa) pada zeolit menghasilkan rendemen HMF yang hampir sama (Tabel 3). Hal ini dapat dihubungkan dengan penentuan keasaman katalis zeolit Ende. Berdasarkan hasil studi keasaman, katalis ZAA, ZAB, Na-ZAA, Na-ZAB, H-ZAA, dan H-ZAB juga memiliki keasaman yang tidak jauh berbeda (Tabel 2). Oleh karena itu, katalis zeolit (ZAA, Na-ZAA, H-ZAA, ZAB, Na-ZAB, H-ZAB) dengan nilai keasaman yang hampir sama memiliki aktivitas katalitik yang tidak berbeda secara signifikan.

Pada substrat berupa glukosa rendemen HMF yang dihasilkan lebih sedikit dibandingkan menggukan substrat berupa fruktosa, yaitu hanya 2-12\%. Hal ini menunjukkan bahwa katalis zeolit Ende memiliki kemampuan yang kurang baik pada proses isomerisasi glukosa menjadi fruktosa. Proses isomerisasi dapat dipengaruhi oleh kekuatan keasaman Lewis pada katalis yang digunakan. Zeolit memiliki pusat $\mathrm{Si}$ dan $\mathrm{Al}$ terkoordinasi 3 yang mempunyai sifat akseptor pasangan elektron (situs Lewis) (Xue et al., 2016). Meskipun zeolit juga memiliki situs Lewis, kekuatan keasaman situs Lewis Si dan Al pada zeolit jauh lebih rendah dibandingkan Cr pada katalis $\mathrm{CrCl}_{3}$ (Zhou et al., 2016). Situs asam Lewis $\left(\mathrm{Cr}^{3+}\right)$ pada $\mathrm{CrCl}_{3}$ memiliki kekuatan asam yang tinggi sebab memiliki orbital $d$ yang kosong. Selain itu, rendahnya isomerisasi yang terjadi juga dapat disebabkan karena bentuk struktur gula yang lebih stabil (Mostapha et al., 2016).

Rasio Si/Al pada zeolit mordenit adalah 4-10 (Gultom et al., 2015). Kemampuan zeolit yang baik dalam menyintesis HMF, yaitu zeolit yang memiliki rasio $\mathrm{Si} / \mathrm{Al}=11$, dengan kemampuan pengubahan fruktosa menjadi HMF 76\% (Fang et al., 2017). Untuk meningkatkan rasio $\mathrm{Si} / \mathrm{Al}$ salah satunya dengan proses dealuminasi menggunakan larutan asam. Proses dealuminasi ini dapat meningkatkan situs asam Brønsted pada zeolit untuk membantu proses dehidrasi pada senyawa gula (Silaghi et al., 
2016; Lei et al., 2013). Hal ini dapat dibuktikan dengan cukup tingginya rendemen HMF yang diperoleh, yaitu sebesar $74.84 \%$ menggunakan katalis ZAA. Akan tetapi, dengan dealuminasi menggunakan asam dapat mengakibatkan berkurangnya ion $\mathrm{Al}^{+}$yang bertindak sebagai asam Lewis, sehingga mempengaruhi proses isomerisasi. Oleh sebab itu, rendemen HMF yang dihasilkan untuk substrat glukosa hanya sebesar $7.87 \%$. Penelitian yang dilakukan Li et al., (2015), menggunakan katalis $\mathrm{H}$-mordenit dengan rasio $\mathrm{Si} / \mathrm{Al}=10$ untuk tranformasi glukosa menjadi HMF menghasilkan rendemen sebesar $14 \%$. Rendemen tersebut tidak jauh berbeda jika dibandingkan dengan rendemen HMF yang dihasilkan menggunakan katalis H-ZAA, yaitu sebesar $12.77 \%$.

\section{SIMPULAN}

ZA, ZAA, Na-ZAA, H-ZAA, ZAB, $\mathrm{Na}-\mathrm{ZAB}$, dan $\mathrm{H}-\mathrm{ZAB}$ memiliki potensi sebagai katalis transformasi senyawa gula (fruktosa dan glukosa) menjadi senyawa HMF. Rendemen yang dihasilkan untuk substrat fruktosa, berkisar 43-74\%, sedangkan untuk substrat glukosa, berkisar 2-12\%. ZAA memiliki kemampuan terbaik sebagai katalis dalam mengkonversi fruktosa menjadi HMF dengan rendemen $74.84 \%$, sedangkan untuk substrat glukosa adalah katalis H-ZAA dengan rendemen $12.77 \%$. Akan tetapi, katalis ini masih memiliki kelemahan dalam reaksi isomerisasi. Oleh karena itu, rendemen HMF yang dihasilkan untuk substrat berupa glukosa masih cukup rendah.

\section{DAFTAR PUSTAKA}

Adeoye JB, Omoleye JA, Ojewumi ME, Babalola R. 2017. Synthesis of Zeolite Y from kaolin using novel method of dealumination. IJAER. 12(5): 755-760.

Fang Z, Smith RL, Qi X. 2017. Production of Platform Chemicals from Sustainable Resources. Singapore: Springer Nature.

Gultom F, Wirjosentono B, Thamrin, Nainggolan H, Eddiyanto. 2015. Preparation and characterization from natural zeolite Sarulla of North Sumatera polyurethane nanocompsite foams. JCMR. 7(10): 20-28.

Hu Z, Liu B, Zhang Z, Chen L. 2013. Conversion of carbohydrates into 5- hydroxymethylfurfural catalyzed by acidic ionic liquids in dimethyl sulfoxide. Ind. Crops Prod. 50(2013): 264-269.

Jae J, Tompsett GA, Foster AJ, Hammond KD, Auerbach SM, Lobo RF, Huber GW. 2011. Investigation into the shape selectivity of zeolite catalysts for biomass conversion. J. Catal. 279(2): 257-268.

Kim K, Ahn H. 2011. The effect of pore structure of zeolite on the adsorption of VOCs and their desorption properties by microwave heating. Micropor. Mesopor. Mat. 152(2012): 78-83.

Lei H, Geng Z, Xing T, Zhen W, Jiaxing X, Lu L, Shijie L. 2013. Catalytic conversion of carbohydrates into 5hydroxymethylfurfural over cellulosederived carbonaceous catalyst in ionic liquid. Bioresour. Technol. 148(2013): 501-507.

Lewkowski J. 2001. Synthesis, chemistry and applications of 5-hydroxymethyl-furfural and its derivatives. Arkivoc .17-54.

Li H, Saravanamurugan S, Yang S, Riisager A. 2015. Direct transformation of carbohydrates to the biofuel 5ethoxymethylfurfural by solid acid catalysts. Green Chem. 18(3): 1-8.

Liu B, Zhang Z, Huang K. 2013. Cellulose sulfuric acid as a bio-supported and recyclable solid acid catalyst for the synthesis of 5hydroxymethylfurfural and 5ethoxymethylfurfural from fructose. Cellulose. 20(4): 2081-2089.

Mostapha M, Jahar NA, Chin SX, Jaafar SNS, Zakaria S, Aizat WM, Azizan KA. 2016. Effect of zeolite catalyst on sugar dehydration for 5-hydroxymethylfurfural synthesis. AIP Conference Proceedings, American Institute of Physics.

Ngapa YD, Sugiarti S, Abidin Z. 2016. Hydrothermal transformation of natural zeolite from Ende-NTT and its application as adsorbent of cationic dye. Indones. J. Chem. 16(2): 138-143.

Qiao Y, Theyssen N, Hou Z. 2015. Acid-catalyzed dehydration of fructose to 5(Hydroxymethyl)furfural. Recycl. Catal. 2(1): 36-60. 
Resasco DE, Sitthisa S, Faria J, Prasomsri T, Ruiz MP. 2011. Furfrals as chemical platform for biofuels production. Trivandrum. 37(2): 661-695.

Shimizu K, Uozumi R, Satsuma A. 2009. Enhanced production of hydroxymethylfurfural from fructose with solid acid catalysts by simple water removal methods. Catal. Comm. 10(14): 1849-1853.

Silaghi MC, Chizallet C, Sauer J, Raybaud P. 2016. Dealumination mechanisms of zeolites and extra-framework aluminum confinement. J. Catal. 339(2016): 242-255.

Syafii F, Sugiarti S, Charlena. 2010. Modifikasi zeolit melalui interaksi dengan $\mathrm{Fe}(\mathrm{OH})_{3}$ untuk meningkatkan Kapasitas Tukar Anion. Prosiding Seminar Nasional Sains III. November 13. Bogor-Indonesia.

Trisunaryanti W. 2016. Material Katalis dan Karakternya. Yogyakarta(ID): Gadjah Mada University Press.

Wang Y, Li H, Gu L, Gan Q, Li Y, Calzaferri G. 2009. Thermally stable luminescent lanthanide complexes in zeolite L. Micropor. Mesopor. Mat. 121(1-3): 1-6.
Warner TE, Klokker MG, Nielsen UG. 2017. Synthesis and characterization of Zeolite $\mathrm{Na}-\mathrm{Y}$ and its conversion to the solid acid Zeolite H-Y. J. Chem. Educ. 94(6): 781785.

Wustoni S, Mukti RR, Wahyudi A, Ismunandar. 2011. Sintesis zeolit mordenit dengan bantuan benih mineral alam Indonesia. Prosiding Seminar Nasional Zeolit VII. Oktober 17-18. Surabaya-Indonesia.

Xue Z, Ma MG, Li Z, Mu T. 2016. Advances in conversion of glucose and cellulose to 5hydroxymethyl furfural over heterogenous catalysts. RSC Adv. 6(101): 98874-98892.

Yongdan L, Yang M, Xinli T. 2010. Biomass into chemicals: Conversion of sugars to furan derivatives by catalytic processes. Appl. Catal. A: Gen. 385(1-2): 1-13.

Zhou C, Zhao J, Yagoub AEA, Ma H,Yu X, Hu J, Bao X, Liu S. 2016. Conversion of glucose into 5-hydroxymethylfurfural in different solvents and catalysts: Reaction kinetics and mechanism. Egyp. J. Petrol. 26(2): 111 . 